\section{CONSUMER INSURANCE LAW - REFORM AT LAST?}

Optimism is growing that recommendations published by the English and Scottish Law Commissions in December 2009 may lead to reform of this long-criticised area of law.

There is a grim history of two earlier failed attempts at reforming insurance law. Proposals for change published by the Law Reform Committee in 1957 and the English Law Commission in 1980 were never implemented. A major factor in these failures was the implacable opposition of the British Insurance Association and its successor, the Association of British Insurers. There is also a wider problem; successive governments have a poor record of finding Parliamentary time for the implementation of Law Commission reports.

As a result of this inertia, modern consumer insurance policies are largely governed by rules settled in commercial cases from the 18th and 19th centuries or found in archaic statutes such as the Life Assurance Act 1774. The last significant statutory intervention in insurance contract law was the Marine Insurance Act 1906, and as a codifying measure many of its provisions were based on existing case law.

The impact of these unsuitable and outdated legal rules is that an insurer will often have a disproportionate remedy for a minor error by the consumer. In cases of nondisclosure or misrepresentation, for example, a policy may be avoided — that is set aside from outset — and any claim rejected. When a claim is made, therefore, an insurer has a financial incentive to search for such an error. The results may be seen in some of the critical illness insurance cases considered by the courts or the Financial Ombudsman Service ("FOS"):

- Multiple sclerosis. In Cuthbertson v Friends Provident, 2006 SLT 567, Valerie Cuthbertson made a claim after a diagnosis of multiple sclerosis. The insurer requested access to her medical records, which it said would be given "careful and sympathetic consideration". Having seen the records it avoided the policy and rejected the claim. The insurer's claims officer later conceded that the only purpose of obtaining the records had been to see if any entry gave grounds for invalidating the policy.

- Cancer. After his wife was diagnosed with leukaemia Mr C made a claim under the critical illness policy which they jointly held. The insurer avoided the policy and rejected the claim, as $\mathrm{Mr} \mathrm{C}$ had failed to disclose on the application form that his wife had suffered unrelated ear infections causing some hearing loss.

- Heart attack. Mr F made a claim after suffering a heart attack. The insurer avoided the policy and rejected the claim, as when applying for insurance

Articles
Pre-packaged administration begins to take shape

Mr F had failed to disclose unconnected problems with his back and neck.

$\mathrm{Mr} \mathrm{C}$ and $\mathrm{Mr} \mathrm{F}$ complained to the FOS. Under its compulsory jurisdiction the FOS makes decisions on the basis of what is "fair and reasonable" and so may disregard fundamental principles of insurance law. It was therefore able to decide that both claims should be paid. However it is plainly unacceptable that complaints were necessary before fair treatment was received. Inevitably it meant there were significant delays before the claims were settled. Insurance is meant to bring peace of mind, not further stress at what is already a very difficult time. Insurers which act in this way not only inflict injustice in individual cases. They also damage the reputation of the insurance industry as a whole and so reduce confidence in the value of insurance.

In Consumer Insurance Law: Pre-contract Disclosure and Misrepresentation the Law Commissions review three aspects of the law: pre-contractual non-disclosure or misrepresentation by the consumer, and basis of the contract clauses. The report includes draft legislation, the Consumer Insurance (Disclosure and Representations) Bill. Broadly speaking the Law Commissions' proposals, outlined below, are based on the existing approach of the FOS.

\section{Abolition of the duty of disclosure}

The earliest clear statement of the duty of disclosure is found in Lord Mansfield's judgment in Carter $v$ Boehm (1766) 3 Burr 1905. When applying for an insurance policy a consumer is obliged to inform the insurer of all material facts even if no questions have been asked. A material fact is one which would have an effect, not necessarily decisive, on the mind of a prudent insurer in assessing the risk or in deciding what premium to charge.

Requiring consumers to peer into the mind of an insurer is setting an unreasonable hurdle at which many will inevitably fall. Yet the results if the consumer fails to disclose a material fact can be disastrous. As noted above, on becoming aware of the true facts an insurer can avoid the policy. This is so regardless of whether the consumer has acted fraudulently, negligently or entirely innocently. Any claim may be rejected, even if there is no link to the 
non-disclosure, and the insurer may recover claims payments already made. The avoidance of the policy is itself a material fact and must be disclosed in subsequent applications for insurance. This may make it more difficult or more expensive to obtain cover.

In Lambert v Co-operative Insurance Society Ltd [1975] 2 Lloyd's Rep 485, Mrs Lambert made a claim for loss of jewellery under an all-risks policy. The insurer discovered that her husband had been convicted of several criminal offences. Although the insurer had at no point asked about such convictions it set the policy aside for non-disclosure and declined to pay the claim.

The Law Commissions recommend that the duty of disclosure should be abolished; if an insurer requires information it must ask clear questions.

\section{Proportionate response to misrepresentation}

The current legal rules for misrepresentation mirror those for non-disclosure and the results are equally harsh. In a case reported by the FOS, Mr M wrongly stated when renewing his household policy that his back door was secured with locks which met the insurer's requirements. He might be forgiven for thinking this was the case as the door had been installed by the insurer's own contractor following a burglary. However when a second burglary occurred the insurer found the wrong locks had been fitted. Although the locks were not a contributory factor in the second burglary, the insurer avoided the policy for misrepresentation and rejected the claim.

Under the Law Commissions' proposals the effect of a misrepresentation will depend on the nature of the consumer's conduct or state of mind. There are three possibilities:

- If a misrepresentation is honest and reasonable the policy will remain in force and the insurer must meet any valid claim.

- If a misrepresentation is careless the insurer will have a compensatory remedy based on what it would have done had it known the true facts. So, for example, if it would have charged double the premium only half the claim will be paid. Or if it would have included an exclusion, that term will retrospectively be written into the policy and taken into account in dealing with the claim.

- If a misrepresentation is reckless or deliberate the insurer may avoid the policy and reject any claims.

\section{Basis of the contract clauses rendered ineffective}

Basis of the contract clauses are found on some consumer insurance application forms and are particularly pernicious in their effect. An apparently innocuous wording - that the answers given by the consumer will form the basis of the contract - converts all such answers into warranties. If a warranty is breached, cover is terminated immediately and automatically. The consequences are catastrophic for the means that cover never commences, even though neither the consumer nor the insurer may be aware of the breach until a claim arises and enquiries are made. The fact which is the subject of the warranty does not have to be material, nor does it need to be linked to the claim. Once a warranty has been breached, cover does not recommence even if the breach is remedied.

The Law Commissions propose that basis of the contract clauses should be rendered of no effect.

\section{Is the Financial Ombudsman Service an adequate substitute for reform?}

The service offered by the FOS is invaluable to consumers but is no substitute for law reform — not least because it is subject to restrictions. To take just one example, the FOS cannot make binding awards in excess of $£ 100,000$. The inadequacy of this figure was demonstrated in recent media reports of the experiences of Mrs Michelle Barber, whose estranged husband was convicted of an arson attack which destroyed her home. After paying to reinstate the property, Mrs Barber's insurer became aware that when applying for insurance she had failed to declare a fine of $£ 100$ which had been imposed when she failed to declare an overpayment of benefits. The insurer avoided Mrs Barber's policy and demanded repayment of the full claims settlement of $£ 241,000$.

\section{Prospects for reform}

Despite past failures there are good reasons to believe that insurance contract law reform may now occur. The Law Commissions' report is widely acknowledged to be an impressive piece of work. Based on extensive research and consultations over a period of nearly five years, it is the culmination of a series of publications - a scoping study, issues papers and a consultation paper. By confining the report to consumer insurance the Law Commissions have avoided the concerns of both insurers and HM Treasury regarding the potential impact on overseas earnings should business insurance law be changed. The issues covered by the report, whilst limited, are those which most frequently give rise to consumer detriment and where there is strong agreement that the current law is unsatisfactory. By drawing heavily on the work of the FOS the Law Commissions have ensured that reform is no leap in the dark — the new law will embody tried and tested solutions which are known to be workable.

In addition there has been a major development in attempts to ensure that more Law Commission reports are implemented. In February 2008 the Procedure Committee of the House of Lords announced that a new procedure for uncontroversial Law Commission Bills was to be tested. Under the procedure much of the necessary scrutiny occurs in committee, reducing the time required on the floor of the House. The second of the two Bills in the test was the Third Parties (Rights against Insurers) Bill. It was introduced into the House of Lords on November 23, 
2009. By March 23, 2010 the measure had passed through both Houses of Parliament and received the Royal Assent.

The advantage of this special procedure in achieving swift implementation of a sensible measure which had been gathering dust since 2001 did not go unnoticed. Henry Bellingham, Shadow Secretary for State for Justice, has urged the Government to make the procedure permanent and referred directly to the outstanding proposals for the reform of insurance contract law. Addressing the Parliamentary Under-Secretary of State for Justice, Bridget Prentice, on March 23, 2010, Bellingham said: "I should like to know what happened to that report and whether a Bill will be coming forward in the near future."

\section{Are the Law Commissions' proposals uncontroversial?}

If the special procedure is made permanent could it be used to implement insurance contract law reform as Bellingham suggests? For the procedure to be used, the Law Commissions' proposals must be "generally agreed to be uncontroversial". Encouragingly this seems to be the case. Even the Association of British Insurers, so long the main barrier to reform, has offered its support:

"We share the Law Commissions' desire that customers should be treated fairly. The insurance industry is committed to ensuring that customers understand their rights and obligations, and have their genuine claims paid quickly. We are pleased that the Law Commissions recognise that best practice throughout the industry, supplemented by FSA regulation and the approach of the FOS, already protects the consumer. The Commissions' proposals give legal status to existing best practices, and brings them together in one place in a clear format."

The Chartered Insurance Institute agrees that the proposed reforms are desirable:

"All in all, as a result of these changes, the underlying contract law will provide a modern and stable foundation on which consumer-friendly innovation and higher standards of practitioner professional knowledge and ethical conduct can be built in the public interest."

Consumer representatives are equally positive. Lola Bello, Legal Services expert at Consumer Focus recently said:

"Consumer Focus would like to see the Law Commissions' recommendations implemented without delay. The current law results in significant numbers of consumers being treated unfairly and so damages confidence in the value of insurance. We believe that the proposed reforms will be beneficial for consumers and insurers alike."

And Jessica Tangye, policy officer at the Trading Standards Institute commented:
"The current legal situation within insurance contract law is letting down consumers through a significant imbalance against the policy holder, often at their greatest hour of need. TSI has been part of the campaign to see law in this area reformed and we fully support the Law Commission's recommendations that are a victory for common sense and fairness. Reform is long overdue and we would like to see government act upon these recommendations as swiftly as possible."

Peter Vicary-Smith, Chief Executive of Which?, also argues for rapid action: "The case for consumer insurance law reform has been comprehensively demonstrated by the Law Commissions in their report. Given it has been over a hundred years since the existing legal regime was put in place, and the multiple failed attempts to sort out this issue since then, Which? now wants to see urgent progress".

Crucially there is agreement between the two main political parties. For the Conservatives, Henry Bellingham is clear: "We have looked at this and are supportive. We feel that these proposals will mean more certainty for both the consumer and the insurance industry." And on November 11, 2009, the Prime Minister, Gordon Brown, anticipating the publication of Consumer Insurance Law, stated that "a change of law is obviously needed".

\section{Next steps}

The General Election will be held on May 6, 2010. Regardless of the outcome, the way forward for consumer insurance law reform is plain. The special procedure for Law Commission Bills should be made permanent or its testing should be extended. Following which the procedure should be used to secure rapid enactment of the Consumer Insurance (Disclosure and Representations) Act 2010.

Consumer insurance law is presently unsatisfactory. It causes serious consumer detriment and an undesirable loss of confidence in the value of insurance. The Law Commissions have conducted extensive research and consultations and produced proposals which appear to have achieved near universal support. Reform is recognised as necessary by both the main political parties. There is simply no reason for further delay. As Peter Vicary-Smith has said: "This is not a partisan political issue - it is simply about ensuring we have an up-to-date legal framework. So I would urge whoever is in government after the General Election to implement the Law Commissions' proposals."

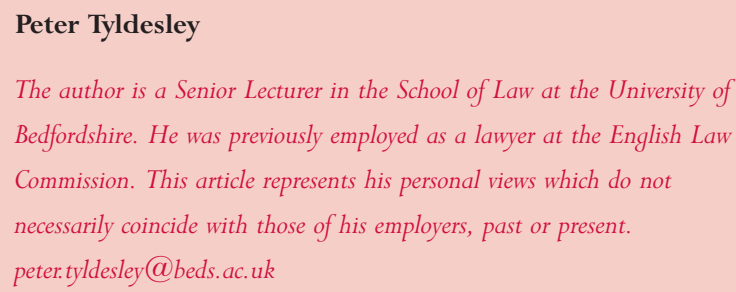

